\title{
Performance of Concrete Containing Fly Ash and Quarry Sand in terms of Workability and Compressive Strength
}

\author{
R. S. Deotale ${ }^{1}$, Dr. A. M. Pande ${ }^{2}$ \\ 'Associate Professor, Civil Engineering Department, Yeshwantrao Chavan College of Engineering, \\ Wanadongari, Nagpur, India \\ ${ }^{2}$ (Director, R\&D, YCCE \& Professor Civil Engg. Department, Yeshwantrao Chavan College of Engineering, \\ Wanadongari, Nagpur, India)
}

\begin{abstract}
Depletion of natural resources and new Environmental laws are preventing restrictive use of natural sand, thus the demand for quarry sand is increasing concrete construction. The properties of quarry sand depend upon basalt rock type from which it is derived. There is need to bring out suitable combination of natural sand and quarry sand along with other admixture to make concrete of desired performance. The present research is aimed at deciding the combination through gradation of aggregates, workability of concrete and compressive strength. It is observed that 55\% natural sand and $45 \%$ quarry sand gives perfect and proper gradation and higher compressive strength and this is may be due to higher quantity of CaO present in quarry sand. The fly ash also has significant contribution in increasing compressive strength and workability of concrete. The results of research study open a new dimension in increasing quarry sand use in concrete construction.
\end{abstract}

Keywords: Cement, Fly ash (FA), Quarry sand, Workability.

\section{Introduction}

Natural river sand is expensive due to excessive cost of transportation from natural sources. Also large scale depletion of these resources create environmental concerns. The river sand possesses the problem of acute shortage in many areas; in such situations quarry sand can be an economic alternative to river sand. The concern about the depletion of natural sources and the effect on environment has particularly focused attention on possibility of use of synthetically produced (from waste materials) aggregates as an alternative to naturally occurring materials. It has become difficult to get river sand of consistent quality in terms of grading requirement and limited silt and clay content. It is because we do not have control over the natural process. Quarry sand (manufactured sand), is the by product that get during process of stone crushing by using vertical shaft impactor (VSI) and makes the crushed stone sand particles good enough to be compared shape and surface texture of natural sand and with well-designed screening system.

The objectives and scope of present studies are

- To study performance of Quarry sand in concrete by partial replacement of Natural sand.

- To study performance of Fly Ash in concrete in combination with Quarry sand.

- To find the optimum percentage of quarry sand in concrete by partial replacement of natural sand.

- To study performance of these concrete under acid attack.

As per G. Balamuruganet, Dr. P. P. Perumal [1] the variation in the strength of concrete when replacing sand by quarry dust from $0 \%$ to $100 \%$ in steps of $10 \%$. From test results it was found that the maximum compressive strength is obtained only at 50\%. The result shows that quarry dust can be utilized in concrete mixtures as a good substitute for natural river sand giving higher strength at 50\% replacement. Priyanka A. Jadhav, Dilip K. Kulkarni. [2]in their studies investigated the effect of water cement ratio on fresh and hardened concrete with partial replacement of natural sand by manufactured sand was investigated concrete mix design of M20 grade was investigated as per Indian Standard code. Workability was measured in terms of slump and compaction factor. The concrete exhibits excellent strength with $60 \%$ replacement of natural sand.

Dr. A. D. Pofale, Syed Raziuddin Quadri [3] studied about the use of crusher dust at 30\%, 40\%, 50\% and $60 \%$ replacement levels, workability of concrete was reduced from 1-6\% and compressive strength increased by $5-22 \%$. Among all mixes highest compressive strength was obtained for $40 \%$ replacement of sand by crusher dust and hence it can be concluded that sand upto 30-60\% can be replaced by crusher dust for economical work. Sreekantan P., George Mathew [4] studied about the influence of presence of higher percentage of fine particles in quarry sand on the mechanical properties of high strength concrete containing fly ash and it is studied that, the higher percentage of fine particles in quarry sand does not affect significantly the engineering properties of high strength concrete when river sand is replaced with 50\% quarry sand along with a $25 \%$ replacement of cement with fly ash. Krishnamoorthi, G. Mohan kumar [5] investigated the workability and 
Performance of Concrete Containing Fly Ash and Quarry Sand in terms of Workability and ..

strength characteristics of quarry dust concrete containing $0 \%$ to $30 \%$ fly ash. Based on results obtained, they concluded that combined use of quarry dust and fly ash improves compressive strength of concrete. Nimitha, Vijayaraghavan, A. S. Wayal [6] in their study replaced river sand by manufactured sand. They have observed that with increasing proportion of manufactured sand up to50 \% compressive strength of concrete increase by $5.7 \%$ and the results show that concrete become harsh with increase in proportion of manufactured sand. M. Uma, S. Shameembanu [7] examined the suitability of replacing the 30\% of Fly Ash and 50\% of Artificial Sand for a Concrete of grade M35. They examined strength characteristics such as Compressive Strength for 7days, 28days, 56days of Curing period and durability characteristics such as Acid Attack Test, Acid Durability Factor, Acid Attack Factor for 30days, 60days, 90days, they analysed results and compared with conventional mix. R. S. Deotale, Dr. A. M. Pande [8] studied the behaviour of concrete containing fly ash and quarry sand. The research is carried out in three phases, the first phase sand is replaced by quarry sand with incremental of $25 \%$ upto $100 \%$ for M25, M30, M35 concrete and determined optimum percentage of replacement at which compressive strength is achieved. They have observed that when natural sand replaced with $50 \%$ quarry sand maximum strength is achieved. In the second phase cement is partially replaced with fly ash by $30 \%$ and $50 \%$, natural sand is replaced by quarry sand, it has been observed that compressive strength is not much affected as compared to controlled concrete. In third phase fly ash is added at $10 \%, 20 \%, 30 \%$ it has been observed that compressive strength slightly increase due extra addition of fly ash.

Gradation of aggregates, physical and chemical properties of fly ash play a major role in achieving desired compressive strength, this have also great relevance in water requirements and achieving workability. Thus it is imperative to understand the performance of concrete containing various percentages of these ingredients. This paper summarises the results obtained and relevance of combinations of various concrete ingredients in achieving concrete performance.

Jie Zhang, Chenchen Gong, Lingchao L [9] conclude that an appropriate amount of Mgo is favourable for the optimization of the mineral composition and the presence of $\mathrm{Na}_{2} \mathrm{O}$ And $\mathrm{K}_{2} \mathrm{O}, \mathrm{MgO}$ as high as $5 \%$ can be introduced into the cement clinker, making it promising for the industrial production of betite-berium calcium sulphoaluminate cement. $\mathrm{A} \mathrm{MgO} 1 \%$ to $5 \%$ promotes hydration rate which can increase the compressive strength of cement but excessive $\mathrm{MgO}$ will lead to negative effect. Since it delay the hydration process

N. Smaoui, M. A. Berube, B. Foufnier, B. Bissonnette, B. Durand [10] concluded that addition alkali in form of NAOH Causes significant reduction in compressive, splitting, direct tensile and flexure strengths of concrete at a ages, which is attributed to a more reticular and more porous cement paste, as observed under the SEM; however for the two alkali contents investigated $(0.6 \%$ and $1.25 \%$ Na2Oe by mass of cement) XRD did not show any difference in the nature of hydrates formed. The reduction in strength due to the higher alkali content.

\section{Materials Used}

Cement : In this study ordinary Portland cement of 43 grade is used conforming to Is 8112-1989 which have specific gravity 3.15 and Normal consistency $32 \%$ initial setting time-55 min and final setting $305 \mathrm{~min}$

Natural Aggregate : Locally available crushed stone conforming to graded aggregate of nominal size $20 \mathrm{~mm}$ and $10 \mathrm{~mm}$ was used in this experimental work. Its specific gravity was 2.85

Sand : Locally available river sand of grading zone II conforming IS 383 and having fineness modulus 2.73, specific gravity 2.54 and Water absorption $1 \%$.

Quarry Sand : Quarry sand was obtained from Siddheshwar quarry, Pachgaon. Plant, Nagpur. Having specific gravity 3.0, Water absorption $2.5 \%$ and fineness modulus 2.57. It has rough surface area. In this study, Quarry sand conforming to grading zone-II conforming IS 383 is used as fine aggregate

Fly Ash : Fly ash used was obtained from Koradi Power Plant Nagpur. The specific gravity of fly ash was 2.2 Physical properties of Fly Ash: (AS per IS 1727-1967)

Water : Potable drinking water was used for making concrete as well as for curing the specimen.

Chemical Admixture : A commercial AC-BV-430 super plasticizer was used to maintain the workability of fresh concrete. The dosage of plasticizer was kept constant in mass basis. It was $1 \%-2 \%$ of cement weight.

\subsection{Chemical Analysis of Concrete Ingredients}

Chemical analysis of Fly Ash, Cement, Natural sand and Quarry sand was carried out to understand relevance of major chemicals in achieving performance of concretes containing these ingredients. Details are presented in table 1 .

Chemical analysis was carried out by-Indian bureau of Mines by XRF Analysis (the values of mineral oxide are given in \% mass) 
Performance of Concrete Containing Fly Ash and Quarry Sand in terms of Workability and ..

\subsection{Grading of aggregate}

The grading of aggregate coarse to fine has marked effect on the workability. Originally in the theory of combined grading, it was assumed that the voids present in the higher size of the aggregate are filled up by the next lower size of aggregate, and similarly, voids created by the lower size are filled up by one size lower than that particle and so on. It was realised later that the voids created by a particular fraction are too small to accommodate the very next lower size. The next lower size being itself bigger than the size of the voids, it will create what is known as "particle size interference", which prevents the large aggregates compacting to their maximum density. As per IS 383:1970 Clause 4.4, gradation of aggregate is carried out. Details are presented in table 2(a) and 2(b).

For each aggregate used in the mix design is included in a gradation analysis. Aggregates are graded not only to maintain cohesiveness of mix, but also to meet the grading requirement of IS 383-1970. The combined aggregate gradation of concrete with replacement of $0 \%, 15 \%, 30 \%, 45 \%, 60 \%, 75 \%, 90 \%$ and $100 \%$ of quarry sand with natural sand is carried out to determine the perfect packing. Since various combinations of natural sand, quarry sand and fly ash were tried it was decided to try gradation curve for all Combinations. As percentage of passing through 150 Micron sieve and 600 Micron sieve are essential for desired performance of concrete and they were plotted for combination chosen. Fig 1 (a) to 1(c) indicate percentage passing of selected combination. The combination containing $45 \%$ quarry sand and $55 \%$ natural sand was specially chosen for further studies the details are shown in Fig 1(e). From figures 1(a) to 1(c) it can be concluded that reading of combined grading for 45\% QS and 55\% NS lies nearly at middle of upper limit and lower limits as specified IS 383-1970.

\section{Experimentation}

The mix proportioning is designed as per the Indian standard recommended method IS 102622009.This research is carried out in seven cases, in each different case mix M25, grade concrete with replacement of $15 \%, 30 \%, 45 \%, 60 \%$ and $100 \%$ of natural sand with quarry sand is carried out to determine the optimum percentage of replacement. And cement is partially replaced by $30 \%$ fly ash. and also the effect of extra fly ash is studied by adding it at $10 \%, 20 \%$, of cement. The effect of water reducer, plasticizer is considered. The different cases, their slumps and compressive strengths are as given table 3 . Water absorption of quarry sand is of much concern, more amount of quarry sand is expected to require more water for workability, and this may also affect compressive strength development. Thus it was decided to add fly ash in some mixes to reduce water requirements and increase compressive strength though pozzolanic properties of fly ash. Testing was carried out as per following provisions of relevant IS code. The compressive strength of cubes were measured after 7, 28, 56, 90 days curing as per IS: 516 - 1959, the flexural strength of beam were measured at 28 days as per IS: 516-1959 and the split tensile strength of cylinder were measured at 28 days as per IS: $5816-1999$.

\section{Observations Based On Experimentation}

To achieve desired properties of concrete containing quarry sand it is essential to carry out chemical analysis, grading of aggregate and workability studies. It is observed that since water absorption of quarry sand is more than that of natural sand, it absorbs more water thus workability of concrete having higher quantity of quarry sand drastically reduces which is seen from Fig. 2(a), 3(a), 4(a), 5(a), 6(a) and 7(a). It is also observed that the replacement of cement by fly ash to around $30 \%$ compensates the loss of workability. The gradation of finer particles in fine aggregate that is percentage passing through 150 micron and 600 micron is essential for deciding desired quantity of natural sand and quarry sand in Concrete Fig. 1(a) and Fig. 1(b) indicate the reason behind choosing $45 \%$ quarry sand and 55\% natural sand. The compressive strength result also indicates this combination is achieving higher strengths in all mixes which can be seen from fig. 2(b) to 7 (b). The chemical analysis of quarry sand sample indicate presence of $\mathrm{CaO}$ to the tune of $12.3 \%$, indicating that the quarry sand also posses cementious property in development of $\mathrm{CSH}$, resulting in increase in compressive strength. However the chemical composition of quarry sand also indicates higher quantity of $\mathrm{Na}_{2} \mathrm{O}$.

The higher quantity of $\mathrm{MgO}$ may result in gain of compressive strength and hardness to concrete. However it is advisable to check the chemical composition of quarry sand before directly in concrete.

\section{Concluding Remark}

1) Quarry sand has more water absorption resulting in loss in workability

2) Quarry sand when used with cement replaced by fly ash or additional fly ash it improves workability and compressive strength of concrete.

3) When different proportion of quarry sand and natural sand are to be used in concrete gradation must be done for different combinations.

4) Chemical composition of quarry sand must be checked before direct use as fine aggregate as higher percentage $\mathrm{CaO}, \mathrm{FeO}_{3} \& \mathrm{Na}_{2} \mathrm{O}$ may affect performance of concrete. 


\section{References}

[1]. Balamurugan,DrP.P.Perumal(2013)"Behaviorof concrete on Use of quarry dust to replace sand in concrete-An Experimental Study” International Journal of Scientific and Research Publications,Vol. 3,No. 6, Dec 2013. pp776-7812.

[2]. Priyanka A. Jadhav and Dilip K. Kulkarni (2012) "An experimental investigation on the properties of concrete containing manufactured sand" International Journal of Advanced Engineering Technology E-ISSN 0976-3945, IJAET/Vol.III/ Issue II/AprilJune, 2012/ PP101-104

[3]. Dr. A. D. Pofale, Syed Raziuddin Quadri 92013) "Effective Utilization of Crusher Dust in Concrete Using Portland Pozzolana Cement" International journal of scientific and Research Publication, Vol 3, Issue 8, August 2013. pp1-7

[4]. Sreekantan P, George Mathew,(2013) "Influence of quarry sand on the properties of high strength concrete containing low calcium fly ash", American Journal of Engineering Research, Vol.2, pp.26-31.

[5]. Krishnamoorthi and G. Mohan kumar (2013)“ Properties of green concrete mix by concurrent use of fly ash and quarry dust " ISOR Journal of Engineering ISSN-2250-3021, volume3, issue 8 (August2013)/V3/PP 48-54.

[6]. Nimitha, Vijayaraghavan, A.S. Wayal, (2013) "Effect of Manufactured Sand on Compressive strength and workability of Concrete", International Journal of structural and civil Engineering Research, Vol.02, no.4, pp.228-232 November 2013

[7]. M. Uma, S. Shameembanu, (2015) "Strength and durability studies on concrete with fly ash and artificial sand", International Journal of Engineering Research and General Science, Vol. 3, No. 1,Jan-Feb 2015.pp138-146

[8]. R. S. Deotale, Dr. A. M. Pande (2015) 'To study the behavior of concrete containing fly ash and quarry sand "International Journal of Research in Engineering and applied Science", Vol 3, No.1,Jan-Feb 2015.pp25-29

[9]. Jie Zhang, Chenchen Gong, Lingchao $\mathrm{Lu}(2015)$ " Effect of $\mathrm{MgO}$ on the composition and properties of betite-Barium Calcium Sulphoaluminate cement in presence of $\mathrm{Na}_{2} \mathrm{O}$ and $\mathrm{K}_{2} \mathrm{O}$. Shandong provincial Key laboratory of preaparation and measurement of building materials, university of jinan250022 PR china .Ceramics-silikaty 59(2) 135-144 (2015)

[10]. N. Smaoli, M.A Berube, B. Foufnier, B. Bissonnette, B. Durand(2005) "Effect of alkali addition on mechanical properties and durability of concrete" science Direct ,Elsevier cement and concrete Research 35(2005) pp203-212

TABLE 1 Details of Chemical Analysis of ingredients of concrete

\begin{tabular}{|l|l|l|l|l|}
\hline & Cement & Fly ash & Natural Sand & Quarry sand \\
\hline $\mathrm{Mineral}$ & \% by mass & \% by mass & \% by mass & \% by mass \\
\hline $\mathrm{Na}_{2} \mathrm{O}$ Sodium oxide & 0.21 & 0.20 & 2.34 & 7.01 \\
\hline $\mathrm{MgO}$ Magnesium oxide & 1.84 & 0.58 & 0.24 & 5.89 \\
\hline $\mathrm{Al}_{2} \mathrm{O}_{3}$ Aluminum trioxide & 15.94 & 32.30 & 11.07 & 6.78 \\
\hline $\mathrm{SiO}_{2}$ Silicon dioxide & 32.52 & 56.85 & 76.93 & 55.51 \\
\hline $\mathrm{P}_{2} \mathrm{O}_{5}$ Phosphorous pentoxide & 0.21 & 0.40 & 0.07 & 0.33 \\
\hline $\mathrm{SO}_{3}$ Sulphur trioxide & 1.71 & 0.26 & 0.05 & 0.11 \\
\hline $\mathrm{K}_{2} \mathrm{O}$ Potassium oxide & 0.98 & 1.02 & 4.47 & 0.06 \\
\hline $\mathrm{CaO}$ Calcium oxide & 38.87 & 0.87 & 0.97 & 12.30 \\
\hline $\mathrm{TiO}_{2}$ Titanium oxide & 1.10 & 1.92 & 0.19 & 3.19 \\
\hline $\mathrm{MnO}_{2}$ Manganese di oxide & 0.05 & 0.05 & 0.08 & 0.35 \\
\hline $\mathrm{Fe}$ O3 Iron trioxide & 4.77 & 4.74 & 2.28 & 6.79 \\
\hline $\mathrm{NiO}-$ Nickel oxide & --- & 0.01 & --- & 0.01 \\
\hline $\mathrm{CuO}$ Copper oxide & 0.008 & 0.01 & 0.005 & 0.04 \\
\hline $\mathrm{SrO}$ Strontium oxide & 0.05 & 0.01 & 0.01 & 0.01 \\
\hline $\mathrm{Zr} \mathrm{O}_{2}$ Zirconium oxide & 0.02 & 0.04 & -- & 0.01 \\
\hline $\mathrm{Cl} \mathrm{Chlorine}$ & 0.01 & 0.01 & 0.01 & 0.03 \\
\hline $\mathrm{RB} \mathrm{O}_{2} \mathrm{O}$ Rubidium oxide & 0.004 & 0.005 & 0.009 & -- \\
\hline $\mathrm{Cr} \mathrm{O}_{3}$ Cromium trioide & 0.02 & 0.003 & 0.04 & 0.01 \\
\hline $\mathrm{PbO}$ lead monoxide & 0.00 & 00 & 0.00 & 00 \\
\hline $\mathrm{BaO}$ Boron oxide & 0.04 & 0.04 & 0.04 & -- \\
\hline
\end{tabular}

TABLE 2 (a) Sieve Analysis for Coarse Aggregate, Quarry Sand and Natural Sand

\begin{tabular}{|c|c|c|c|c|c|c|c|c|}
\hline Sieve $\mathrm{mm}$ & $\begin{array}{l}\text { Lower } \\
\text { Limit }\end{array}$ & $\begin{array}{l}\text { Upper } \\
\text { Limit }\end{array}$ & $\begin{array}{lr}\text { Q.S } & 15 \% \\
\text { and } & \text { N.S } \\
85 \% & \end{array}$ & $\begin{array}{lr}\text { Q.S } & 30 \% \\
\text { and } & \text { N.S } \\
70 \% & \\
\end{array}$ & $\begin{array}{lr}\text { Q.S } & 45 \% \\
\text { and } & \text { N.S } \\
55 \% & \\
\end{array}$ & $\begin{array}{lr}\text { Q.S } & 60 \% \\
\text { and } & \text { N.S } \\
40 \% & \\
\end{array}$ & $\begin{array}{lr}\text { Q.S } & 75 \% \\
\text { and } & \text { N.S } \\
25 \% & \\
\end{array}$ & $\begin{array}{lr}\text { Q.S } & 90 \% \\
\text { and } & \text { N.S } \\
10 \% & \end{array}$ \\
\hline 0.15 & 0 & 6 & 2.26 & 2.98 & 3.73 & 4.49 & 5.25 & 6.00 \\
\hline 0.6 & 10 & 35 & 19.79 & 19.00 & 18.21 & 17.43 & 16.642 & 15.85 \\
\hline 4.75 & 30 & 50 & 40.67 & 40.77 & 40.83 & 40.89 & 40.96 & 41.02 \\
\hline 20 & 95 & 100 & 96.52 & 96.52 & 96.52 & 96.52 & 96.52 & 96.52 \\
\hline 40 & 100 & 100 & 100 & 100 & 100 & 100 & 100 & 100 \\
\hline
\end{tabular}

TABLE 2 (b) Combined gradation for Quarry sand and Natural sand

\begin{tabular}{|l|l|l|l|l|}
\hline & \multicolumn{4}{|l|}{ Percentage Passing } \\
\hline Sieve Sizes mm & $20 \mathrm{~mm}$ & $10 \mathrm{~mm}$ & Quarry sand & Natural Sand \\
\hline 40 & 100 & 100 & 100 & 100 \\
\hline 20 & 94.0 & 100 & 100 & 100 \\
\hline 10 & 0.4 & 75 & 100 & 100 \\
\hline 4.75 & 0 & 19.81 & 97.5 & 96.5 \\
\hline 2.36 & - & 0.6 & 86 & 90.5 \\
\hline 1.18 & - & 0 & 55 & 75.5 \\
\hline 0.6 & - & - & 48.45 & 55.5 \\
\hline
\end{tabular}


Performance of Concrete Containing Fly Ash and Quarry Sand in terms of Workability and ..

\begin{tabular}{|l|l|l|l|l|}
\hline 0.3 & - & - & 34.5 & 27.6 \\
\hline 0.15 & - & - & 21.5 & 3.0 \\
\hline Fineness modulus & & & 2.57 & 2.59 \\
\hline Conforming to Zone & & & Zone II & Zone II \\
\hline
\end{tabular}

TABLE 3 Workability and Compressive Strength of M25 concrete with various combinations

\begin{tabular}{|c|c|c|c|c|c|c|}
\hline \multirow[t]{2}{*}{ Type of mix } & \multirow{2}{*}{$\begin{array}{l}\text { Identification } \\
\text { symbol }\end{array}$} & \multirow{2}{*}{$\begin{array}{l}\text { Slump } \\
(\mathbf{m m})\end{array}$} & \multicolumn{4}{|c|}{ Compressive Strength in MPa } \\
\hline & & & 7 Days & 28 Days & 56 Days & 90 Days \\
\hline CM+N.S $100 \%$ & M25-A & 140 & 25.47 & 28.25 & 29.40 & 32.30 \\
\hline $\mathrm{CM}+\mathrm{QS} 15 \%$ & M25-A1 & 120 & 26.44 & 29.34 & 31.30 & 32.70 \\
\hline CM+QS $30 \%$ & M25-A2 & 80 & 28.93 & 29.70 & 32.63 & 33.70 \\
\hline CM+QS $45 \%$ & M25-A3 & 75 & 29.12 & 32.20 & 33.70 & 33.90 \\
\hline CM+QS 60\% & M25-A4 & 70 & 28.30 & 31.50 & 32.90 & 33.00 \\
\hline CM+N.S 100\%+WR- (controlled mix) & M25-B & 140 & 23.60 & 26.33 & 28.50 & 30.40 \\
\hline $\mathrm{CM}+\mathrm{QS} 15 \%+\mathrm{WR}$ & M25-B1 & 120 & 24.29 & 27.41 & 29.80 & 31.50 \\
\hline $\mathrm{CM}+\mathrm{QS} 30 \%+\mathrm{WR}$ & M25-B2 & 90 & 25.30 & 29.23 & 30.10 & 31.70 \\
\hline $\mathrm{CM}+\mathrm{QS} 45 \%+\mathrm{WR}$ & M25-B3 & 85 & 25.70 & 29.80 & 31.50 & 32.60 \\
\hline CM+QS 60\%+WR & M25-B4 & 75 & 24.90 & 28.60 & 29.10 & 31.80 \\
\hline CM $70 \%+F A 30 \%$ & M25-C & 140 & 24.10 & 26.90 & 30.88 & 31.10 \\
\hline CM 70\%+FA 30\%+ QS 15\% & M25-C1 & 120 & 24.10 & 28.20 & 31.10 & 31.70 \\
\hline CM 70\%+FA 30\% + QS 30\% & $\mathrm{M} 25-\mathrm{C} 2$ & 90 & 25.70 & 30.02 & 32.00 & 32.60 \\
\hline CM 70\%+FA 30\% + QS 45\% & M25-C3 & 80 & 26.20 & 31.20 & 32.70 & 33.30 \\
\hline CM $70 \%+$ FA $30 \%+$ QS $60 \%$ & M25-C4 & 75 & 25.50 & 30.40 & 31.90 & 32.80 \\
\hline CM 70\%+FA 30\%+WR & M25-D & 160 & 22,00 & 27.00 & 27.40 & 28.20 \\
\hline CM70\%+FA30\%+QS!5\%+WR & M25-D1 & 145 & 23.60 & 26.93 & 27.90 & 29.00 \\
\hline CM 70\%+FA 30\% + QS 30\%+WR & M25-D2 & 140 & 24.29 & 28.00 & 28.30 & 30.40 \\
\hline CM 70\%+FA 30\% + QS 45\%+WR & M25-D3 & 120 & 25.30 & 28.30 & 29.70 & 31.70 \\
\hline CM 70\%+FA 30\% + QS 60\%+WR & M25-D4 & 100 & 24.40 & 27.50 & 28,00 & 30.10 \\
\hline CM+FA $10 \%$ (extra)+WR & M25-E & 150 & 24.00 & 26.90 & 30.88 & 31.10 \\
\hline CM+FA $10 \%$ (extra)+QS 15\%+WR & M25-E1 & 120 & 24.10 & 28.20 & 31.10 & 31.70 \\
\hline CM+FA10\%(extra) +QS 30\%+WR & M25-E2 & 100 & 25.70 & 30.02 & 32,00 & 32.60 \\
\hline CM+FA10\%(extra) +QS 45\%+WR & M25-E3 & 80 & 26.20 & 31.20 & 32.70 & 33.30 \\
\hline CM+FA $10 \%$ (extra) +QS 60\%+WR & M25-E4 & 75 & 25.50 & 30.40 & 31.90 & 32.80 \\
\hline CM+FA $20 \%($ extra $)+W R$ & M25-F & 160 & 25.55 & 28.17 & 28.80 & 31.68 \\
\hline CM+FA $20 \%$ (extra) +QS 15\%+WR & M25-F1 & 130 & 26.70 & 28.80 & 29.70 & 31.81 \\
\hline CM+FA $20 \%$ (extra) +QS 30\%+WR & $\mathrm{M} 25-\mathrm{F} 2$ & 110 & 27.50 & 30.21 & 31.50 & 32.15 \\
\hline CM+FA $20 \%$ (extra) +QS 45\%+WR & M25-F3 & 100 & 28.00 & 31.10 & 32.40 & 33.00 \\
\hline CM+FA $20 \%$ (extra) +QS 60\%+WR & M25-F4 & 80 & 27.40 & 31.60 & 32.00 & 32.10 \\
\hline CM+Q.S 100\% +WR & M25-G & 80 & 15.50 & 19.55 & 24.00 & 25.27 \\
\hline
\end{tabular}

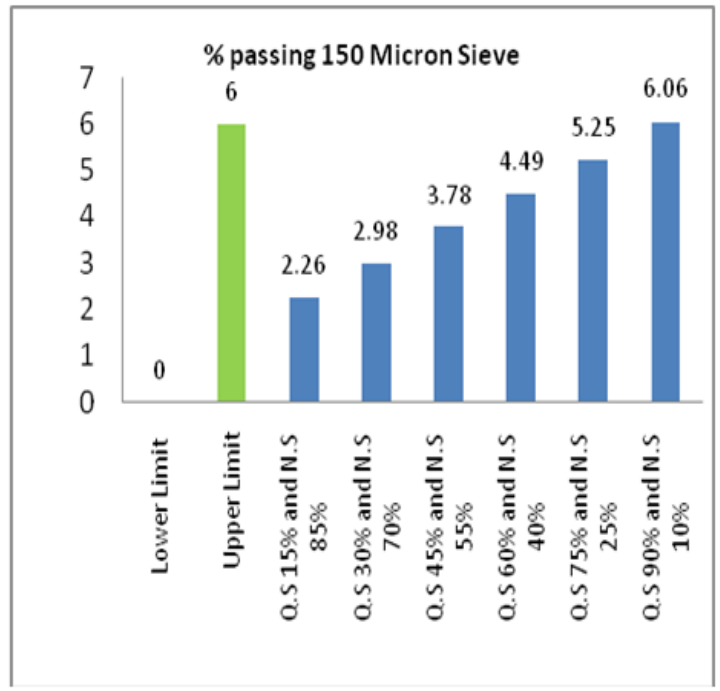

Fig. 1 (a) Combined Grading for different combinations of quarry sand and Natural sand (150-micron sieve)

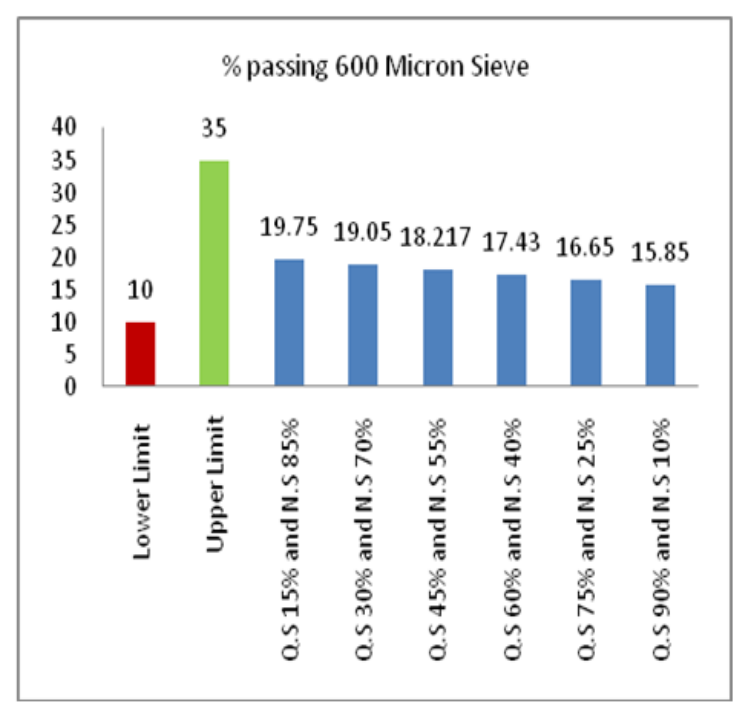

Fig. 1 (b) Combined Grading for different combinations of quarry sand and Natural sand (600-micron sieve) 


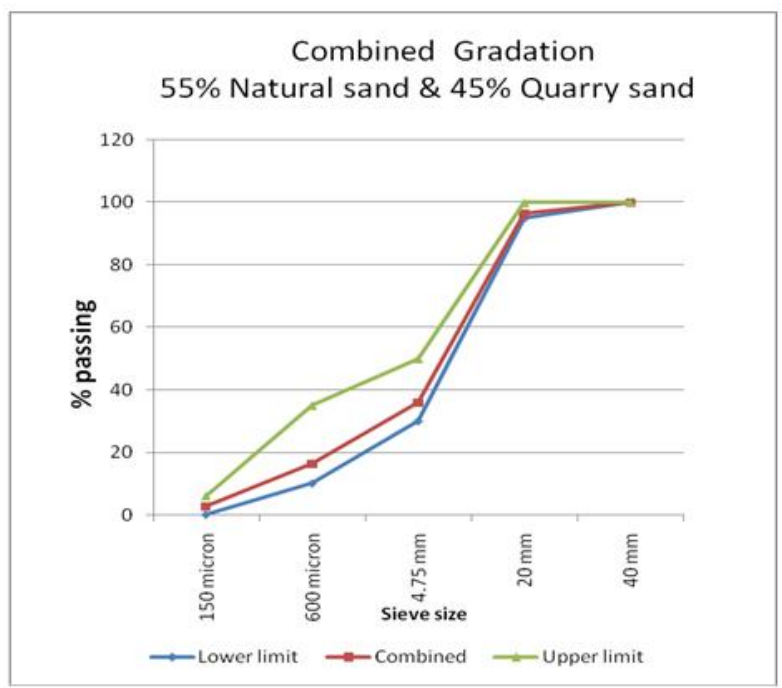

Fig. 1 (c) - Combined grading for $45 \% \mathrm{QS}$ and 55\%NS

Case 1 - Replacement of Natural Sand with Quarry Sand. (without plasticiser)
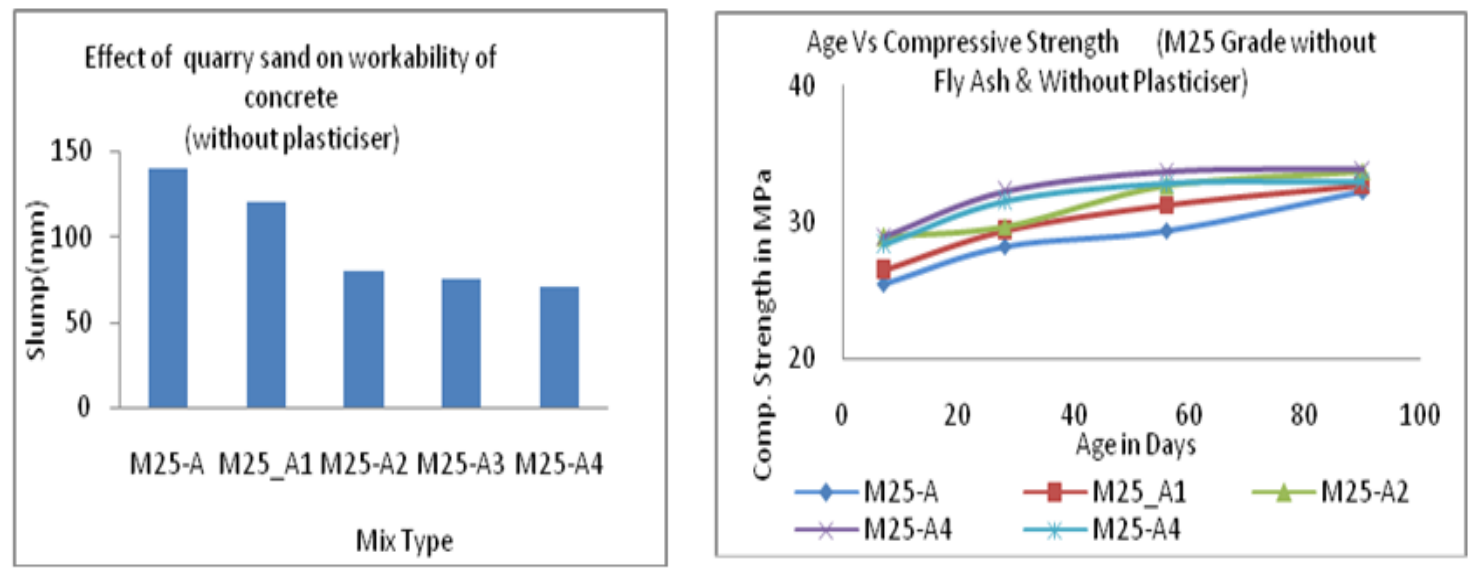

Fig. 2 (a) - slump (mm) with variation of quarry sand with variation of quarry sand. (Without plasticiser)

Fig 2 (b) - compressive strength (Mpa) with variation of quarry sand (without plasticiser)

Case 2 - Replacement of Natural sand with Quarry sand (with plasticiser)

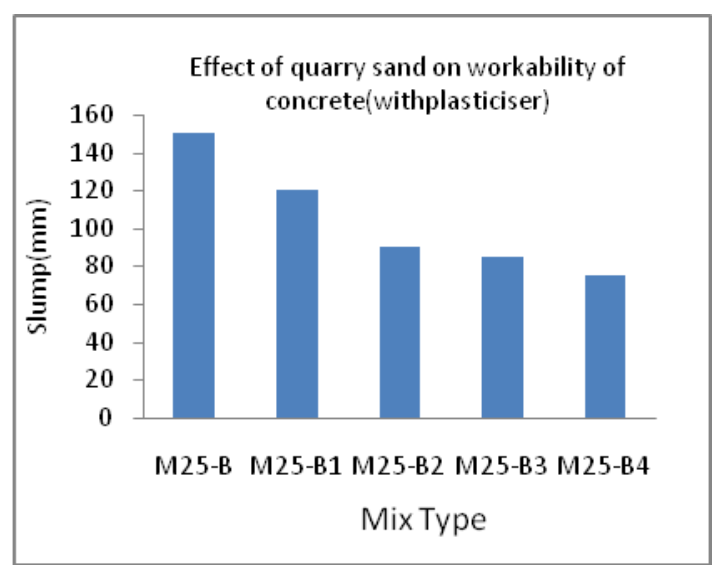

Fig. 3 (a) - slump (mm) with variation of quarry sand With variation of quarry sand.(With plasticiser )

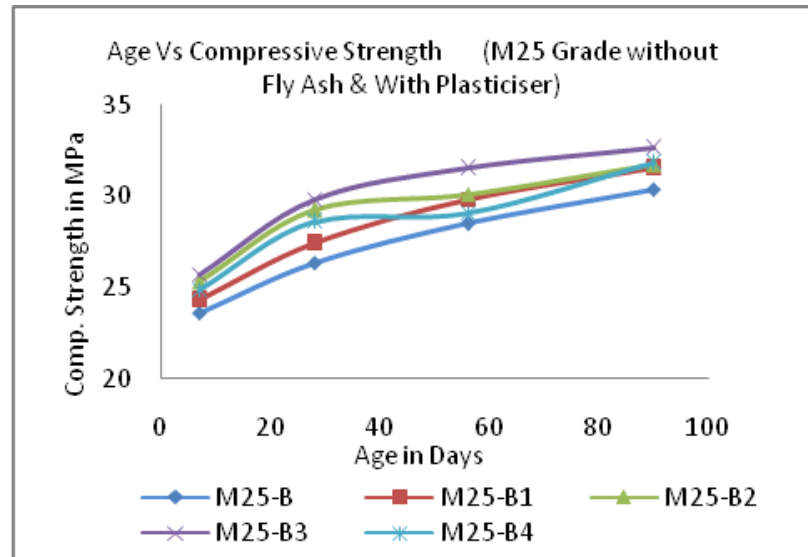

Fig. 3 (b) - compressive strength (Mpa) with variation of quarry sand (with plasticiser) 
Performance of Concrete Containing Fly Ash and Quarry Sand in terms of Workability and ..

Case 3 - Replacement of Natural sand by Quarry sand with Fly ash (without plasticizer)

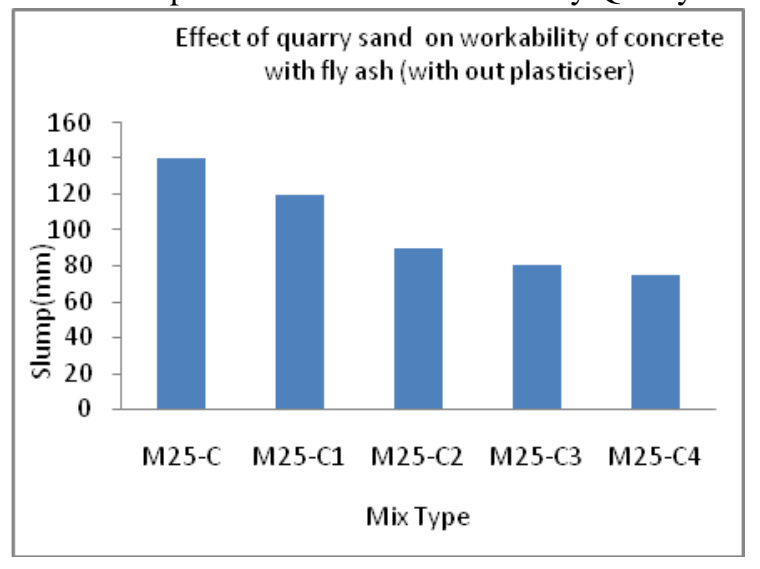

Fig. 4 (a) - slump (mm) with variation of quarry sand with fly ash. (Without plasticiser)

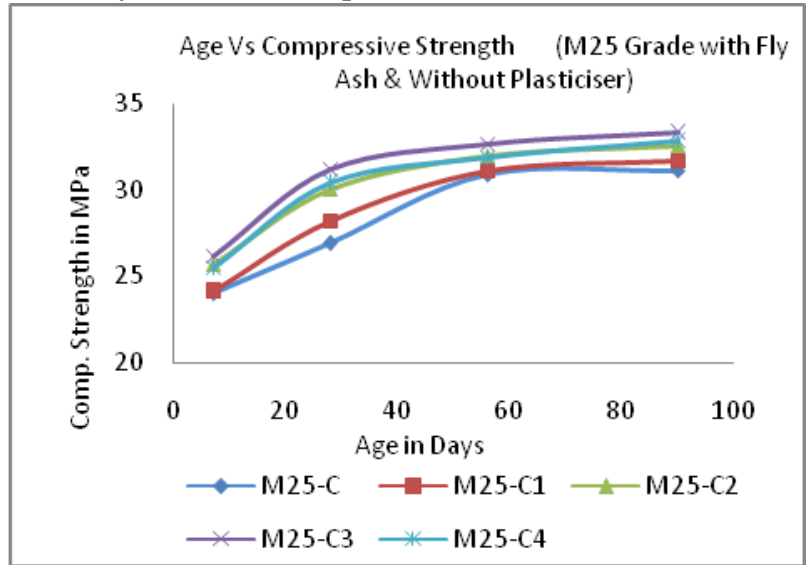

Fig. 4 (b) - compressive strength (Mpa) with fly ash with variation of quarry sand (Without plasticiser)

Case 4 - Replacement of Natural sand by Quarry sand with Fly ash (with plasticizer)

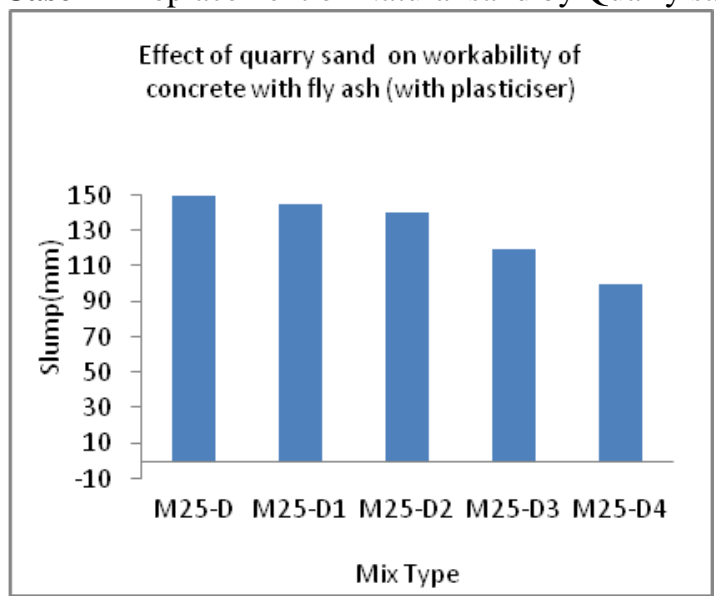

Fig. 5 (a) - slump (mm) with variation of quarry sand with fly ash (With plasticiser )

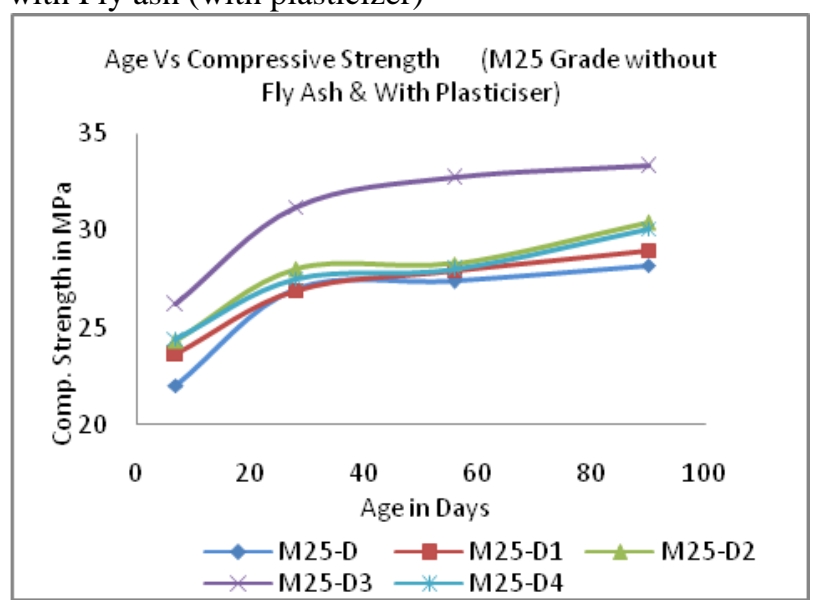

Fig. 5 (b) - compressive strength (Mpa) with variation of quarry sand with fly ash. (With plasticiser )

Case 5 - Replacement of Natural sand with Quarry sand and 10\% fly ash (with plasticizer)

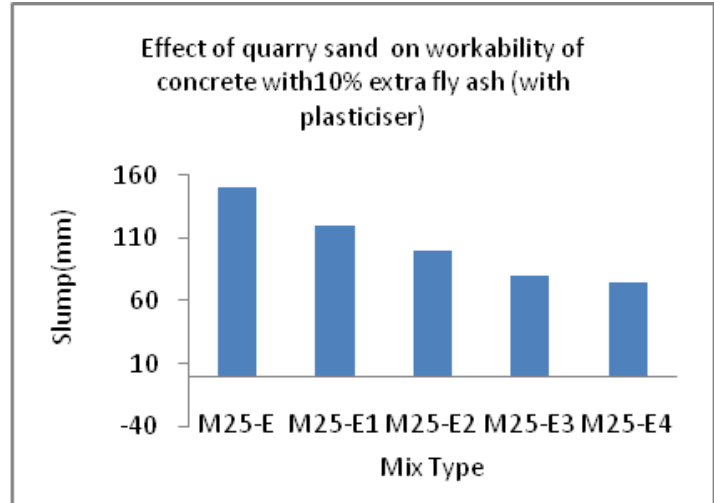

Fig. 6 (a) - slump with variation of quarry sand with $10 \%$ extra fly ash (with plasticizer)

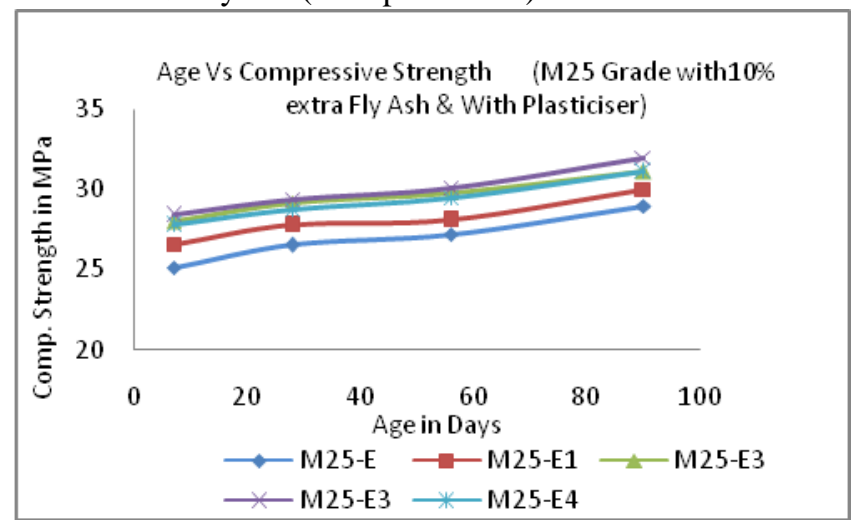

Fig. 6 (b) - compressive strength (Mpa) with variation of quarry sand with $10 \%$ extra fly ash (with plasticizer) 
Performance of Concrete Containing Fly Ash and Quarry Sand in terms of Workability and ..

Case 6 - Replacement of Natural sand with Quarry sand and 20\% fly ash (with plasticizer)

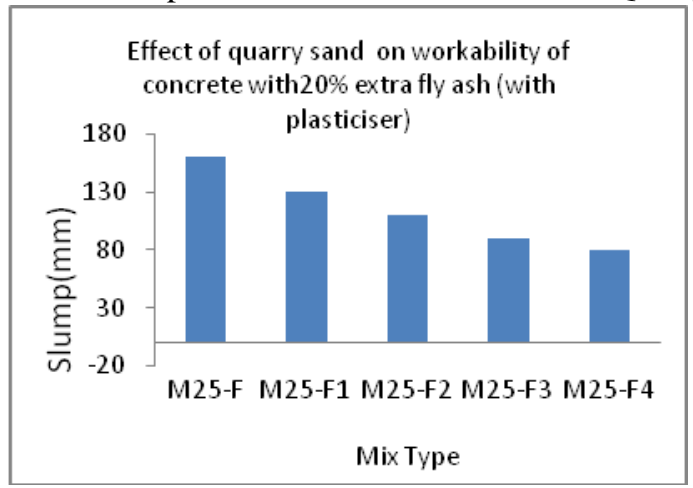

Fig. 7 (a) - slump with variation of quarry sand with $20 \%$ extra fly ash (with plasticizer )

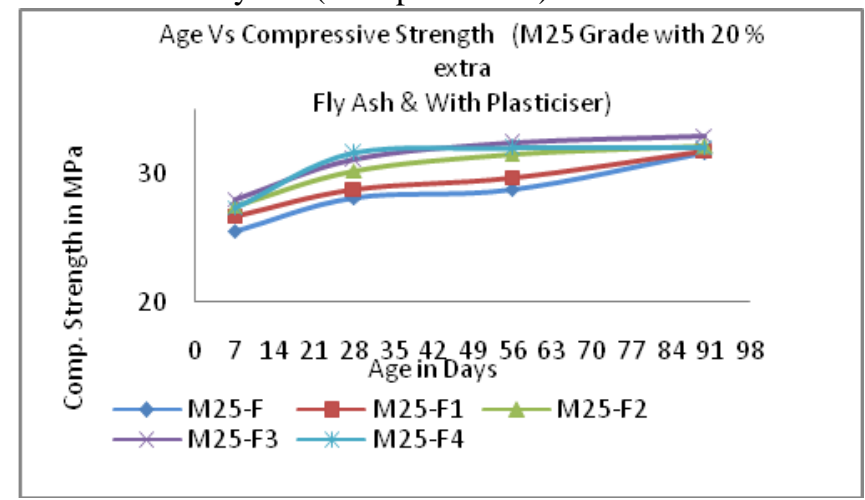

Fig. 7 (b) - compressive strength (Mpa) with variation of quarry sand with $20 \%$ extra fly ash (with plasticizer) 